\title{
Parasitic contamination of drinking water and its prevalence among handlers
}

\section{and sheep}

Zainab A. Makawi and Mohammed Th. S. Al-Zubaidi

Department of Parasitology, College of Veterinary Medicine, Baghdad University, Iraq.

E-mail: mohabood24@gmail.com

Received: 4/6/2017

Accepted: $31 / 7 / 2017$

\section{Summary}

The current study was designed to determine the infection rate of intestinal protozoa in sheep and their handlers, and in their drinking water, in Wasit province, so as to study the relationship between contamination of drinking water with protozoal pathogen and infection in sheep and handlers in the period from the beginning of September 2015 to the end of February 2016. Two hundred eighty fecal samples were collected: (180) samples from sheep and 100 samples from human (50 handlers and 50 from non handlers), 50 drinking water samples were collected (18 samples; human tap water and RO bottled water and 32 samples river water). All samples were examined by conventional methods (direct moist smears, flotation with saturated sugar solution and stained with Modified acid fast, Giemsa and lugol's iodine ) The total infection rate in sheep, handlers and drinking water samples were $83.33 \%, 72 \%, 84.37 \%$ and $33.33 \%$ respectively. The result showed that drinking water samples of sheep and handlers were contaminated with protozoal oocysts or cysts of Cryptosporidium spp. (65.62\%) (27.77 \%), Giardia lamblia (6.25\%) (0), Entamoeba spp (68.75\%) (0), Eimeria spp (25\%) (5.55\%) and Buxtonella sulcata $(40.62 \%)(0)$.

Keywords: Contamination, Water, Protozoa, Sheep, Sheep handlers.

\section{Introduction}

Parasitic diseases play a considerable role for responsibility of infectious diseases globally and they also cause important enteric sickness (1). Several intestinal protozoan parasites cause zoonotic disease associated with livestock, domestic creatures. The open farms cause transmission of infection to humans (2). Infections usually happen through consumption of cysts/oocysts damaging raw meals or normal standard water (3 and 4). Enteric protozoa are a different group of unicellular parasites inhabiting the intestinal tract in great vertebrate hosts such as human and animals. When diarrhea is relatively a regular indication for this harmful parasite but without symptoms colonization is also typical (5). Protozoan parasite becomes a growing issue of public health and veterinary importance (6). Worldwide, protozoal is anticipated to be influenced by changes in rainfall quantity, intensity, regularity, and duration. Drinking water can be contaminated by sewage and waste from animal activity, or rotting animal carcasses. In addition, the parasites that contaminate open water resources, such as reservoirs, ponds, and waterways have been provided by domestic and wildlife inhabiting this environment (7 and $8)$.

Consequently, environmental conditions in developing countries predispose to the transmitting of water-borne disease (9). The clinical symptoms of intestinal protozoal infections, include giardiasis, coccidiosis and cryptosporidiosis, showing almost similar symptoms, loss of appetite, nausea, vomiting, throwing up, soft to watery diarrhea, malabsorption, dehydration and stomach pains (10). People attacked by these diseases suffer from a significant issue of poor hygienic in the areas and loss of personal hygiene such as rural areas (11). There are several researches on pollution of drinking water with harmful protozoa in the Middle East (12-14), whereas there is scarce knowledge about them in Iraq (15-18). The aim of this study was to determine the infection rate of intestinal protozoa in sheep and their shepherds and their drinking water.

\section{Materials and Methods}

280 fecal samples were collected: (180) fecal samples from sheep whose ages ranged from 7-36 months including 37 males and 137 females, and 100 stool samples from human (50 handlers and 50 from non-handlers) whose ages ranged from 10-40 years including 68 
males and 32 females, from three different regions (Al-Hafriya, Al- Al-Suwaira and AlAziziyah) of Wasit province and during the period from the beginning of September 2015 to the end of February 2016. In addition 50 water samples were collected (18 samples of human tap water, RO bottled water, and 32 samples of sheep river water). All samples were collected in clean sterilized and secured $100 \mathrm{ml}$ plastic containers. Information was recorded (place, date of sampling, age and sex of human and animals). Then samples were transported in the cooling box to the Department of Parasitological/ Faculty of Veterinary Medicine/ University of Baghdad for examination. All samples were examined by conventional methods (direct moist smears, flotation with saturated sugar solution and stained with Modified acid fast, Giemsa and lugol's iodine) for detection of oocysts and cysts of these protozoal parasites (19 and 20).

Statistical analysis: The Chi-square test was used for the comparison between the results. Differences were considered statistically significant at $\mathrm{P}<0.05$ (21).

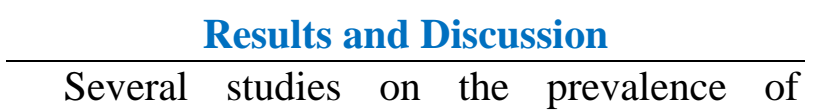
intestinal protozoa have been done all over the world and have shown variations in the rate of infections depending on geographical regions and localities, sanitary environment and hygienic habits of people living there (22). The results of this study showed that the overall infection rate of intestinal protozoa in sheep collected from the three regions of Waist province was $83.33 \%$ comparable with $72 \%$ in human, without significant differences between the studied regions (Table, 1). These results were in agreement with (23), who recorded an infection rate with intestinal protozoa reaching up $85 \%$ in lambs in Baghdad Province with some protozoal infection (Cryptosporidium spp, Giardia spp, Eimeria spp) in sheep. The study recoded infection rate with intestinal protozoa $(84.37 \%)$ in (27) samples from the total (32) samples of sheep drinking water (river water) and recorded a higher infection rate in AlSuwaira $(90.90 \%)$, and lower infection rate in Al-Hafriya (80\%), while the study found $(33.33 \%)$ in (6) samples from overall (18) handlers drinking water (Table, 1$)$. This result agreed with (22 and 24) who detected some intestinal protozoa (G. lamblia, and $C$. parvum) in water sources.

Table, 1: Relation between contaminated water and infection of sheep and handlers with intestinal Protozoa according to areas.

\begin{tabular}{|c|c|c|c|c|c|c|c|c|}
\hline \multirow[b]{2}{*}{ Area of study } & \multicolumn{2}{|c|}{ Types of samples } & \multicolumn{2}{|c|}{ No. of Samples examined } & \multicolumn{2}{|c|}{ No. of positive } & \multicolumn{2}{|c|}{ Percentage $\%$} \\
\hline & Feces & $\begin{array}{l}\text { Drinking } \\
\text { water }\end{array}$ & Feces & $\begin{array}{l}\text { Drinking } \\
\text { water }\end{array}$ & Feces & $\begin{array}{l}\text { Drinking } \\
\text { water }\end{array}$ & Feces & $\begin{array}{l}\text { Drinking } \\
\text { water }\end{array}$ \\
\hline \multirow[t]{3}{*}{ Al-Hafriya } & Sheep & Sheep & 60 & 10 & 49 & 8 & $81.66 \mathrm{~b}$ & 80 b \\
\hline & Handlers & Handlers & 18 & 6 & 10 & 2 & 55.55 & 33,33 \\
\hline & Non handlers & & 18 & & $\mathbf{0}$ & & $\mathbf{0}$ & \\
\hline \multirow[t]{3}{*}{ Al-Suwaira } & Sheep & Sheep & 60 & 11 & 55 & 10 & 91.66 a & $90.90 \mathrm{a}$ \\
\hline & Handlers & Handlers & 16 & 6 & 14 & 3 & 87.5 & 50 \\
\hline & Non handlers & & 16 & & 2 & & 12.5 & \\
\hline \multirow[t]{3}{*}{ Al-Aziziyah } & Sheep & Sheep & 60 & 11 & 46 & 9 & $76.66 \mathrm{~b}$ & $81.81 b$ \\
\hline & Handlers & Handlers & 16 & 6 & 12 & 1 & 75 & 16.66 \\
\hline & Non handlers & & 16 & & 2 & & 12.5 & \\
\hline \multirow[t]{3}{*}{ Total } & Sheep & Sheep & 180 & 32 & 150 & 27 & 83.33 & 84.37 \\
\hline & Handlers & Handlers & 50 & 18 & 36 & 6 & 72 & 33.33 \\
\hline & Non handlers & & 50 & & 4 & & 8 & \\
\hline
\end{tabular}

Different superscript refers to significant differnces at $\mathrm{P}<0.05$

The infection rate of protozoal parasites in sheep and human fecal samples $(50.55,52 \%)$, $(6.11,24 \%),(39.44,12 \%),(23.33 \%, 0)$ and $(12.77 \%, 0)$ is as follows: Cryptosporidium spp, Giardia spp, Entamoeba spp, Eimeria spp and Buxtonella sulcata, respectively.
Moreover, results of this study approved that Eimeria spp and Buxtonella sulcata were not observed in human stool. Nevertheless, only Entamoeba spp was recognized in the nonhandlers stool (Table, 2). Regarding the distribution of these protozoa in sheep and 
human, the results of this study approved the zoonotic impact and nature of some parasites.
However, some of the protozoa didn't show this zoonotic impact (25 and 26).

Table, 2: Relation between contamination of water and infection of sheep and handlers with Intestinal Protozoa according to the genus of parasites

\begin{tabular}{|c|c|c|c|c|c|c|c|c|}
\hline \multirow[b]{2}{*}{ Genus of Parasites } & \multicolumn{2}{|c|}{ Types of samples } & \multicolumn{2}{|c|}{ No. of Samples examined } & \multicolumn{2}{|c|}{ No. of positive } & \multicolumn{2}{|c|}{ Percentage $\%$} \\
\hline & Feces & $\begin{array}{l}\text { Drinking } \\
\text { water }\end{array}$ & Feces & $\begin{array}{c}\text { Drinking } \\
\text { water }\end{array}$ & Feces & $\begin{array}{l}\text { Drinking } \\
\text { water }\end{array}$ & Feces & $\begin{array}{c}\text { Drinking } \\
\text { water }\end{array}$ \\
\hline \multirow{3}{*}{$\begin{array}{c}\text { Cryptosporidium } \\
\text { Spp }\end{array}$} & Sheep & Sheep & 180 & 32 & 91 & 21 & $50.55 \mathrm{a}$ & $65.62 \mathrm{a}$ \\
\hline & Handlers & Handlers & 50 & 18 & 26 & 5 & 52 & 27.77 \\
\hline & Non handlers & & 50 & & $\mathbf{0}$ & & $\mathbf{0}$ & \\
\hline \multirow{3}{*}{ Giardia Spp } & Sheep & Sheep & 180 & 32 & 11 & 2 & $6.11 \mathrm{~b}$ & $6.25 \mathrm{~b}$ \\
\hline & Handlers & Handlers & 50 & 18 & 12 & $\mathbf{0}$ & 24 & 0 \\
\hline & Non handlers & & 50 & & $\mathbf{0}$ & & $\mathbf{0}$ & \\
\hline \multirow{3}{*}{ Entamoeba Spp } & Sheep & Sheep & 180 & 32 & 71 & 22 & 39.44 a & $68.75 \mathrm{a}$ \\
\hline & Handlers & Handlers & 50 & 18 & 6 & 0 & 12 & 0 \\
\hline & Non handlers & & 50 & & $\mathbf{0}$ & & $\mathbf{0}$ & \\
\hline \multirow{3}{*}{ Eimeria Spp } & Sheep & Sheep & 180 & 32 & 42 & 8 & $23.33 \mathrm{~b}$ & $25 \mathrm{~b}$ \\
\hline & Handlers & Handlers & 50 & 18 & $\mathbf{0}$ & 1 & 0 & 5.55 \\
\hline & Non handlers & & 50 & & $\mathbf{0}$ & & & \\
\hline \multirow{3}{*}{ Buxtonella sulcata } & Sheep & Sheep & 180 & 32 & 23 & 13 & 12.77 & 40.62 \\
\hline & Handlers & Handlers & $\mathbf{5 0}$ & 18 & $\mathbf{0}$ & $\mathbf{0}$ & 0 & 0 \\
\hline & Non Handlers & & 50 & & $\mathbf{0}$ & & $\mathbf{0}$ & \\
\hline
\end{tabular}

Different superscript refers to significant differnces at $\mathrm{P}<0.05$

The study recorded infection rate with Cryptosporidium spp (Fig. 1 and 2) in drinking water of sheep and handlers $(65.62,27.77 \%)$ respectively, while recorded infection rate with Giardia spp (Fig, 3 and 4) and Entamoeba spp (Fig, 5 and 6) in drinking water of sheep only (6.25 and $68.75 \%$ ). Also the result showed an infection rate with Eimeria spp (Fig, 7 and 8) in sheep and handlers drinking water reaching $(25,5.55 \%)$ respectively, while the result recorded an infection rate with Buxtonella sulcata (Fig, 9 and 10) in sheep fecal samples and sheep drinking water only $(12.77,40.62 \%)$ respectively, (Table, 2). These results agreed with (27) in Basrah who recorded contamination of drinking water samples $(36.4 \%)$, and also agreed with (28) in Baghdad province who recorded rate of contamination of piped water samples $(25.3 \%)$. (29) recorded $(19.34 \%)$ in river water and (30) recorded rate $(25 \%)$ in tap water in Baghdad city contamination with intestinal protozoa, (31) in India recorded contamination of plain water with intestinal protozoa $(41.66 \%)$, due to low socio-economic status and contamination of water sources of sheep drinking water with Waste of humans and animals which is considered an important source of prevalence of several intestinal parasites. As well the emergence of infection among people who use piped drinking water may be attributable to retro gradation in the water networks in the cities (31).
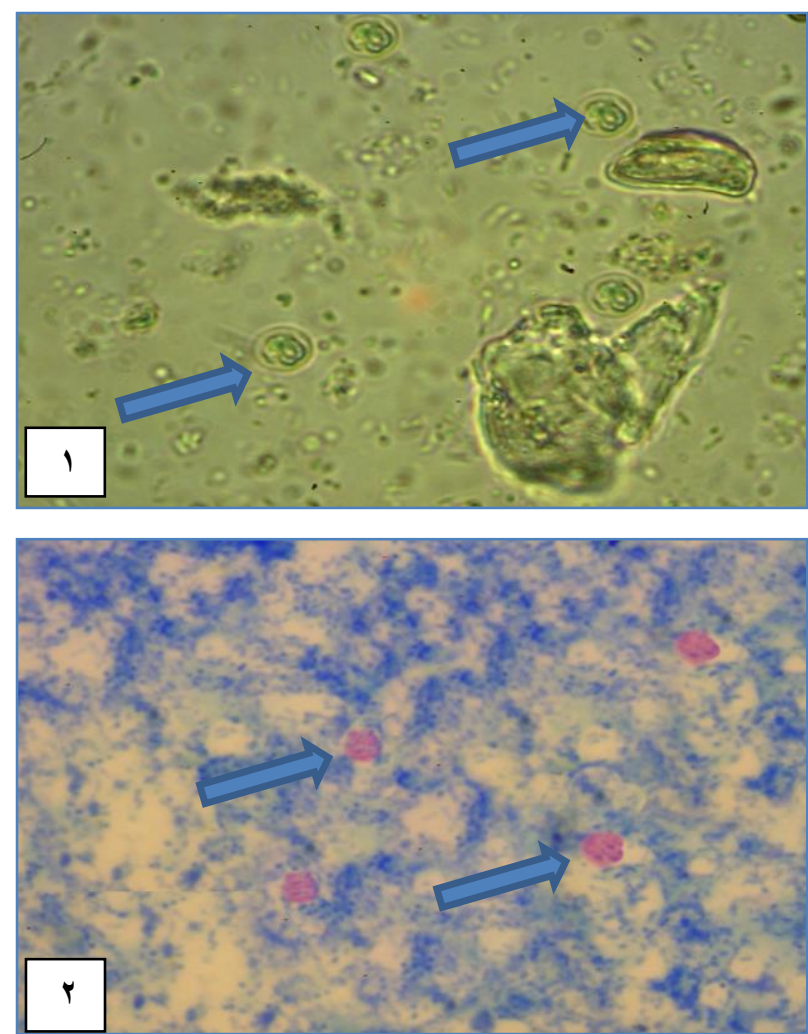

Figure, 1 and 2: Cryptosporidium spp. oocyst in fecal sample of sheep, direct wet film (1), stained with Modified acid fast (2), (100x). 

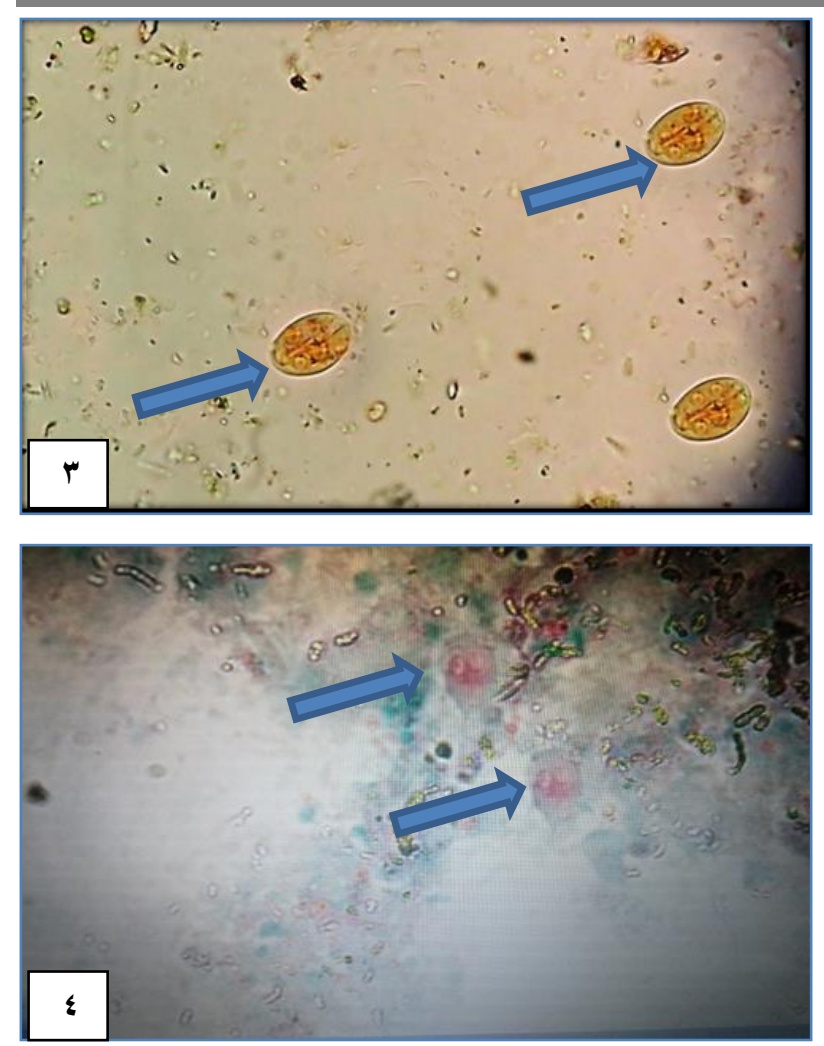

Figure, 3 and 4: Giardia spp cyst (3), trophozoite in sheep fecal sample stained with Lugols Iodine and Giemsa stain (4), (100x).
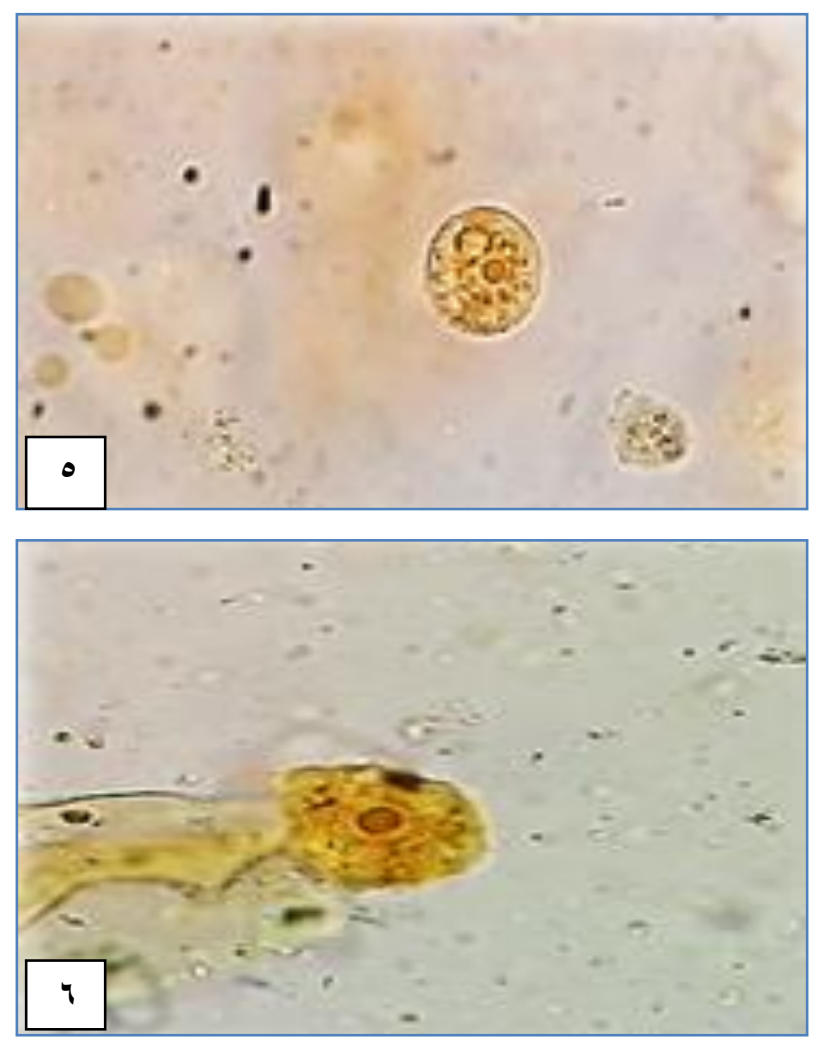

Figure, 5 and 6: Entamobea spp cyst in handlers stool sample (5), Trophozite in fecal sample of sheep stained with Lugols Iodine stain (6), (100x).
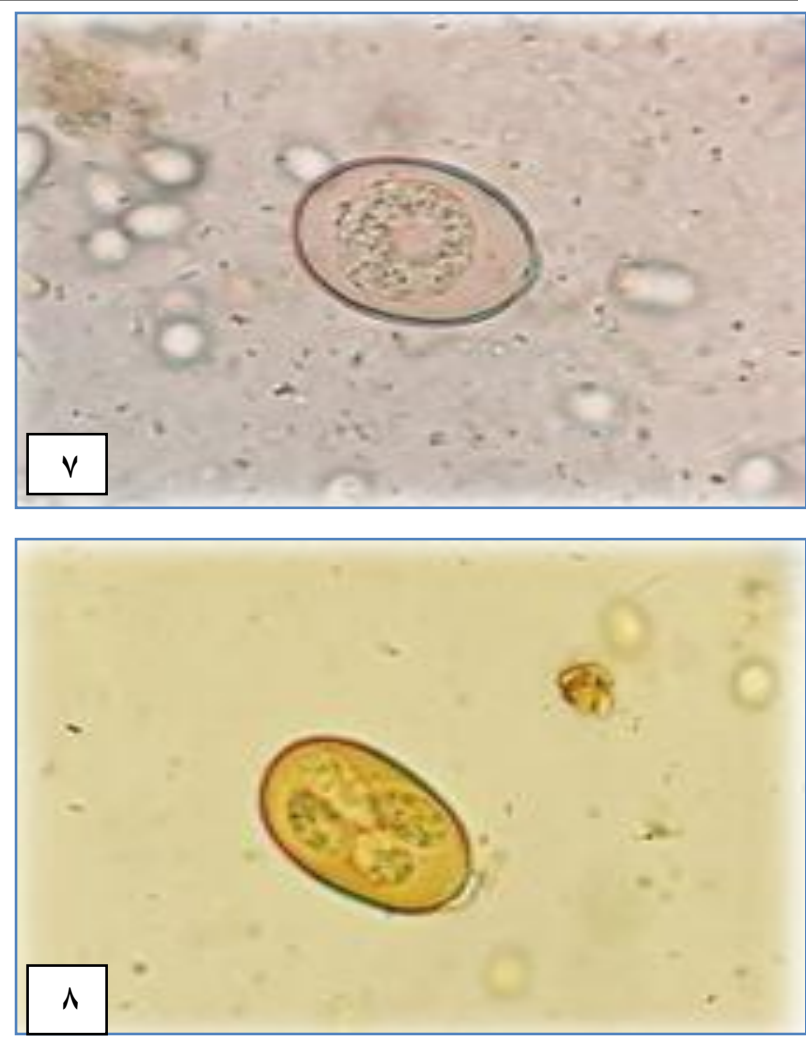

Figure, 7 and 8: Eimeria spp oocyst (7) unsporulated, sporulated oocyst stained with lugols Iodine $(8),(100 x)$ in sheep fecal samples.

The results of this study recorded the highest infection rate $(100 \%)$ in sheep and sheep drinking water contamination in September, November and December, while the lowest infection rate was during February $(36.66 \%)$ with significant differences $(\mathrm{P}>0.05)$. The results also showed that the sheep handlers revealed highest infection rate with intestinal protozoa in September and December $(85.71 \%)$, while the lowest infection rate was during November and February $(55.55 \%)$ with significant differences $(\mathrm{P}>0.05)$ (Table, 3). This result agreed with (32) in Diyala province who recorded highest infection rate in November and lowest in February, and also agreed with (23) who recorded the highest infection rate in December (100\%) and January (95.65\%), while the lowest infection rate in June $(66.67 \%)$ in Baghdad province, and (33) who recorded highest infection in Autumn season. Also the results are compatible with (33) who recoded same results in same months, and explained these variations in infection rate as being due to the existence of suitable environmental factors such as temperature and 
moisture which facilitated spread and completing the life cycle of these parasites.
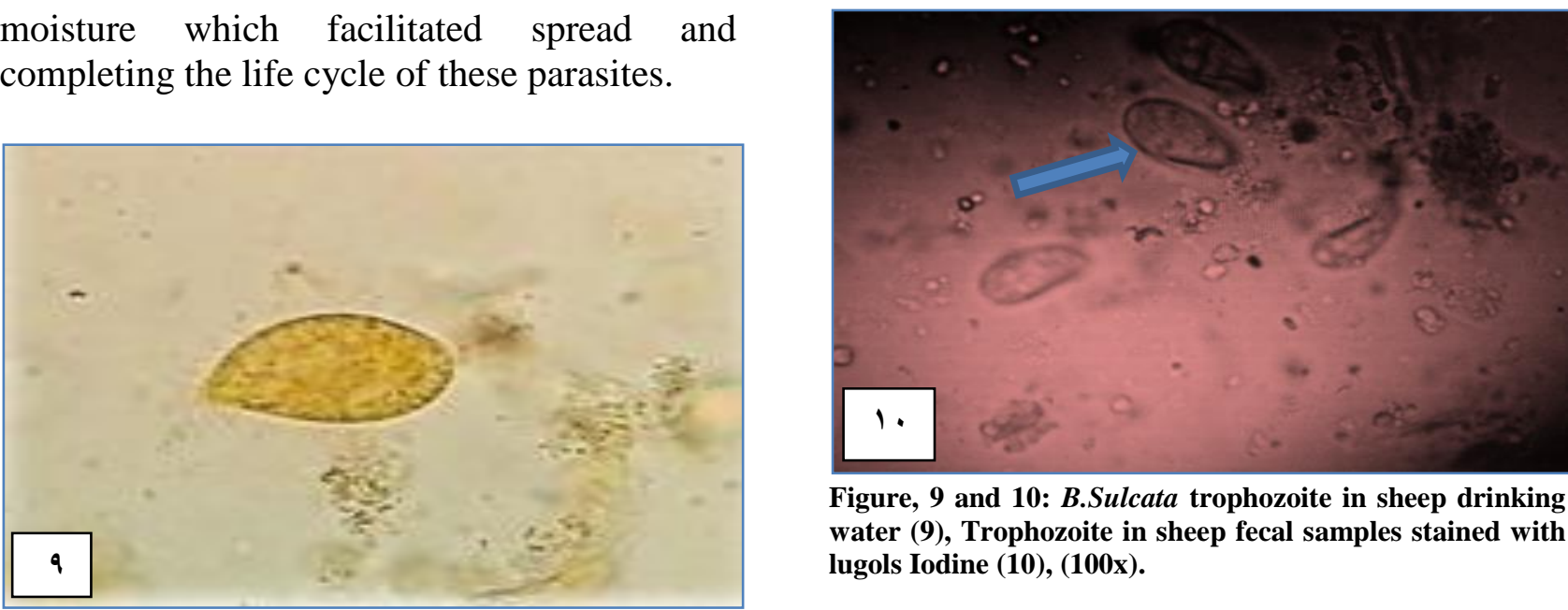

Figure, 9 and 10: B.Sulcata trophozoite in sheep drinking water (9), Trophozoite in sheep fecal samples stained with lugols Iodine (10), (100x).

Table, 3: Relation between contaminated water and infection of sheep and handlers with Intestinal Protozoa according to months.

\begin{tabular}{|c|c|c|c|c|c|c|c|c|}
\hline \multirow{2}{*}{$\begin{array}{l}\text { Months of } \\
\text { study }\end{array}$} & \multicolumn{2}{|c|}{ Types of samples } & \multicolumn{2}{|c|}{ No. of Samples examined } & \multicolumn{2}{|c|}{ No. of positive } & \multicolumn{2}{|c|}{ Percentage \% } \\
\hline & Feces & $\begin{array}{l}\text { Drinking } \\
\text { water }\end{array}$ & Feces & $\begin{array}{l}\text { Drinking } \\
\text { water }\end{array}$ & Feces & $\begin{array}{c}\text { Drinking } \\
\text { water }\end{array}$ & Feces & $\begin{array}{c}\text { Drinking } \\
\text { water }\end{array}$ \\
\hline \multirow[t]{3}{*}{ September } & Sheep & Sheep & 30 & 6 & 30 & 6 & $100 \mathrm{a}$ & $100 \mathrm{a}$ \\
\hline & Handlers & Handlers & 18 & 3 & 6 & 2 & 85.71a & 66.66 \\
\hline & Non handlers & & 18 & & $\mathbf{0}$ & & $\mathbf{0}$ & \\
\hline \multirow[t]{3}{*}{ October } & Sheep & Sheep & 30 & 5 & 25 & 4 & 83.33 a & $80 \mathrm{~b}$ \\
\hline & Handlers & Handlers & 9 & 3 & 7 & 2 & 77.77 b & 66.66 \\
\hline & Non handlers & & 9 & & $\mathbf{0}$ & & & \\
\hline \multirow[t]{3}{*}{ November } & Sheep & Sheep & 30 & 5 & 30 & 5 & $100 \mathrm{a}$ & 100 a \\
\hline & Handlers & Handlers & 16 & 3 & 5 & 1 & $55.55 b$ & 16.66 \\
\hline & Non handlers & & 16 & & $\mathbf{0}$ & & 0 & \\
\hline \multirow[t]{3}{*}{ December } & Sheep & Sheep & 30 & 5 & 30 & 5 & $100 \mathrm{a}$ & $100 \mathrm{a}$ \\
\hline & Handlers & Handlers & 16 & 3 & 6 & 1 & $85.71 \mathrm{~b}$ & 16.66 \\
\hline & Non handlers & & 16 & & $\mathbf{0}$ & & $12.5 \mathrm{c}$ & \\
\hline \multirow[t]{4}{*}{ January } & Sheep & Sheep & 30 & 6 & 24 & 4 & 83.33 b & $66.66 \mathrm{~b}$ \\
\hline & & Handlers & 9 & 3 & 7 & $\mathbf{0}$ & $77.77 \mathrm{~b}$ & 0 \\
\hline & Handlers & & 9 & & 2 & & $22.22 \mathrm{c}$ & \\
\hline & Non handlers & & & & & & & \\
\hline \multirow[t]{3}{*}{ February } & Sheep & Sheep & 30 & 5 & 11 & 3 & $36.66 \mathrm{~b}$ & $60 \mathrm{~b}$ \\
\hline & Handlers & Handlers & 9 & 3 & 5 & $\mathbf{0}$ & $55.55 b$ & $\mathbf{0}$ \\
\hline & Non handlers & & 9 & & 2 & & $22.22 \mathrm{c}$ & \\
\hline \multirow[t]{3}{*}{ Total } & Sheep & Sheep & 180 & 32 & 150 & 27 & 83.33 & 40.62 \\
\hline & Handlers & Handlers & 50 & 18 & 36 & 6 & 72 & 33.33 \\
\hline & Non handlers & & 50 & & 4 & & 8 & \\
\hline
\end{tabular}

Different superscript refers to significant differnces at $P<0.05$

The highest infection rate with intestinal protozoa was in age group (7-12 month) (91.42\%), while the lowest infection rate $(76.19 \%)$ in age group (19-24 month) with significant differences $(\mathrm{P}>0.05)$. While the highest infection rate of human with intestinal protozoa were recorded in the age groups (2130 years) and (10-20 years) $(83.33,80 \%)$ respectively, and the lowest infection rate
(25\%) was recorded in age group (31-40 years) (Table, 4). These results are compatible with (26 and 34) in Baghdad and Diyala governorates who found that younger animals showed higher susceptibility to infection than adults and this is mostly related to lower immune status, crowding stress and managements in the farm, where much of sheep get in contact in or access into the 
infected fields without any preparation plan against the infection.

Table, 4: Infection rate of intestinal protozoa according to age groups.

\begin{tabular}{|c|c|c|c|c|}
\hline $\begin{array}{l}\text { Age } \\
\text { groups }\end{array}$ & $\begin{array}{l}\text { Types of } \\
\text { samples }\end{array}$ & $\begin{array}{c}\text { No. of } \\
\text { Samples } \\
\text { Examined }\end{array}$ & $\begin{array}{l}\text { No. of } \\
\text { positive }\end{array}$ & $\begin{array}{c}\text { Percentage } \\
\%\end{array}$ \\
\hline \multirow{5}{*}{$\begin{array}{c}\text { Sheep } \\
\text { (months) }\end{array}$} & $7-12$ & 70 & 64 & $91.42 \mathrm{a}$ \\
\hline & 13-18 & 15 & 12 & 80b \\
\hline & $19-24$ & 42 & 32 & 76.19 b \\
\hline & $25-30$ & 27 & 22 & 81.48 a \\
\hline & $31-36$ & 26 & 20 & 76.92 b \\
\hline \multirow{3}{*}{$\begin{array}{c}\text { Handlers } \\
\text { (years) }\end{array}$} & $10-20$ & 30 & 24 & $80 b$ \\
\hline & 21-30 & 12 & 10 & 83.33 a \\
\hline & $31-40$ & 8 & 2 & $25 \mathrm{c}$ \\
\hline Non & $10-20$ & 18 & 0 & $\mathbf{0}$ \\
\hline handlers & $21-30$ & 20 & 2 & $10 \mathrm{~b}$ \\
\hline (Years) & $31-40$ & 12 & 2 & $16.66 \mathrm{a}$ \\
\hline
\end{tabular}

Different superscript refers to significant differnces at $P<0.05$.

This study recorded highest infection rate of intestinal protozoa in male sheep and male handlers as $(90.69,75 \%)$ respectively, while the lowest infection rate in females (81.02, $66.66 \%$ ) respectively, while the highest infection rate of intestinal protozoa in non handlers $(14.28 \%)$ in females (Table, 5). This result was in accordance with (34) who recorded highest infection rate in males in Diyala Province, while it did not agree with (35) who recorded highest infection rate in females in Diwaniyah province.

Table, 5: Infection rate of intestinal protozoa according to sex.

\begin{tabular}{|c|c|c|c|c|}
\hline Sex & $\begin{array}{l}\text { Types of } \\
\text { samples }\end{array}$ & $\begin{array}{c}\text { No. of } \\
\text { Samples } \\
\text { examined }\end{array}$ & $\begin{array}{l}\text { No. of } \\
\text { positive }\end{array}$ & $\begin{array}{c}\text { Percentage } \\
\%\end{array}$ \\
\hline \multirow{3}{*}{ Male } & Sheep & 43 & 39 & 90.69 a \\
\hline & Handlers & 32 & 24 & 75 a \\
\hline & Non handlers & 36 & 2 & $5.55 \mathrm{c}$ \\
\hline \multirow{3}{*}{ Female } & Sheep & 137 & 111 & $81.02 \mathrm{~b}$ \\
\hline & Handlers & 18 & 12 & $66.66 \mathrm{~b}$ \\
\hline & Non handlers & 14 & 2 & $14.28 \mathrm{c}$ \\
\hline \multirow{3}{*}{ Total } & Sheep & 180 & 150 & 83.33 \\
\hline & Handlers & 50 & 36 & 72 \\
\hline & Non handlers & 50 & 4 & 8 \\
\hline
\end{tabular}

Different superscript refers to significant differnces at $P<0.05$.

\section{References}

1. Ortega, Y.R.; Eberhard, M.L. and Kris, H. (2008). Protozoan diseases, cryptosporidiosis, giardiasis and other intestinal protozoan, diseases. Pp:354-366. In Inter. Encyclo. Pub. Hea. Acad. Pre., Oxford, Uni. King.,.

2. Chalmers, R.M. and Giles, M. (2010). Zoonotic cryptosporidiosis in the UK challenges for control. J. Appl. Microbiol., 109:1487-149.

3. Baldursson, S. and Karanis, P. (2011). Waterborne transmission of protozoan parasites: review of worldwide outbreaksan update 2004-2010, Water Res., 45(20):6603-6614.

4. Torgerson, P.R.; De Silva, N.R. and Fèvre, E.M. (2014). The global burden of foodborne parasitic diseases: An update, Trends in Parasi., 30(1): 20-26.

5. Cama, V.A. and Mathison, B.A. (2015). Infections by intestinal coccidia and Giardia duodenalis, Clinic. in Lab. Medi., 35(2):423444.

6. Dixon, B.; Parrington, L.; Cook, A.;Pintar, K.; Pollari, F.; Kelton, D. and Farber, J. (2011). The potential for zoonotic transmission of Giardia duodenalis and Cryptosporidium spp. from beef and dairy cattle in Ontario, Canada. Vet. Parasitol., 175:20-26.

7. Girones, R.; Ferrús, M.A.; Alonso, J.L.; Rodriguez-Manzano, J.; Calgua, B.; Corrêa Ade, A.; Hundesa, A.; Carratala, A. and Bofill-Mas, S. (2010). Molecular detection of pathogens in water-the pros and cons of molecular techniques. Water Res., 44(15): 4325-4339.

8. Srisuphanunt, M.; Karanis. P.; Charoenca, N.; Boonkhao, N. and Ongerth, J.E. (2010). Cryptosporidium and Giardia detection in environmental waters of southwest coastal areas of Thailand. Parasitol. Res., 106:12991306.

9. Harper, S.; Edge, V.; Schuster-Wallace, C.; Berke, O. and McEwen, S. (2011). Weather, water quality and infectious gastrointestinal illness in two Inuit communities in Nunatsiavut, Canada: potential implications for climate change. Eco. Hea., Pp:1-16.

10. Hall, A.; Hewitt, G.; Tuffrey, V. and de Silva, N.A. (2008). Review and meta-analysis of the impact of intestinal worms on child growth and nutrition. Matern. Child. Nutr., 4:118236. 
11. Garcia, L.S. and Bruckner, D.A. (1993). Diagnostic medical parasitology, $2^{\text {nd }}$ ed. Amer. Soc. Microbiol., Washington, Pp:764.

12. Hamadi, S. and Al-Mohamed, Y. (1999). Estimation of the Residues of Pesticides, Bacteria and Parasites in the Surface and Ground waters at Damascus Gouta., 15(2).

13. Bakir, B.; Tanyukse, M.; Saylam, F.; Tanriverdi, S.; Araz, R.E.; Hacim, A.K. and Hasde, M. (2003). Investigation of Waterborne Parasites in Drinking Water Sources of Ankara, Turkey. J. Microbiol., 41(2):148-151.

14. Yosefi, Z.; Hezarjaribi, H.Z.; Enayati, A.A. and Mohammadpoor, R.A. (2009). Parasitic contamination of wells drinking water in Mazandaran province. Iran. J. Environ. Hea. Sci. Eng., 6(4):241-246.

15. Al-Fahdawi, H.A. (2002). Study on the contamination of different water sources with pathogenic parasites in Ramadi city. MSc Thesis. College of Scie. Al-Anbar. Uni.

16. Hadi, A.M. and Faraj, A.A. (2008). Distribution of intestinal parasites in drinking water in some regions in Baghdad. ALQadisiyah J. Vet. Med. Sci., 7(2):33-36.

17. Hadi, A.M. and Makawi, Z.A. (2013). Pathogenic intestinal parasites found in fresh water of the Tigris River, 17(11):608-619.

18. Al-Morshidy, K.A.H. and Al-Amari, M.J.Y. (2015). Detection of parasitic contamination in Hilla city drinking water/ Babylon province/ Iraq. Advances in Natural and Applied Sci., 9(3):80-84.

19. Coles, E.H. (1986). Veterinary clinical pathology ( $4^{\text {th }}$ ed.) W.B. Saunders Company Philadelphia. Pp:374-453.

20. Markell, E.K. Voge, M and John, D (1986). Medical Parasitology $6^{\text {th }}$ ed. W.B. Sandeas Company, London.

21. Snedecor, G.W. and Cochran, W.G. (1989). Statistical Methods, $8^{\text {th }}$ ed., Iowa State University Press.

22. Marshall MM, Naumovitz D, Ortega Y and Sterling C. (1997). Waterborne Protozoan Pathogens. Clin. Microbiol. Rev., 10:67-85.

23. Abd Al-Wahab, I.H. (2003). Study in the epidemiology of the intestinal protozoa (Eimeria spp. Cryptosporidium spp. Giardia spp.) in the sheep in Baghdad province. MSc Thesis, College of Veterinary Medicine, University of Baghdad.
24. Cai, J.; Ye, J.; Du, H.L.; Hu, X.W.; Liu, J.; Huang, W.; Cui, X. (2007). Investigation of Cryptosporidium and Giardia contaminating drinking-water in Chengdu. Chin. J. Health Lab. Technol., 17:2165-2167.

25. Al-Zubaidi, M.T. and Al-Mayah, K.S. (2011). Prevalence Buxtonella sulcata in neonatal and young calves in AL-Nasir station and some regions in Baghdad (ALShuala and Gazaliya). Iraqi J. of Sci., 52(4): 420-424.

26. Al-Seady, H.H.O. and kawan, M.H. (2014). Prevalence of Buxtonella sulcata in neonatal and young lambs in three regions in Baghdad city (Abu Ghraib,Yusufiya and Mahmudiya). J. of Kerbala Uni., 12:4.

27. Jarallah, H.M. (2016). Contamination of Different Drinking Water Sources with Parasites in Basrah Marshes Villages, Iraq. J. of Babylon University/ Pure and Applied Sciences, 24(2):370-376.

28. Fadhel, A.I. (2010). Diagnosis of some parasite Isolated from drinking water and seasonal vegetables in Baghdad province. Msc. Thesis collage of Vet. Med. Baghdad University .Iraq.

29. Al-Dulaimi, F.H.A.; Al-Hamairy, A.K.A.; Shlash, S.A. and Al Hussaini, F.M.H. (2013). Investigation of parasites in drinking water sources of three suburban in Babylon province. J. of Babylon University. Pure and Applied Sci., 21(3):812-817.

30. Abbas, P.M.; AL-Saqur, I.M. and Majeed, H.A. (2016). Detection and genotyping of giardia lamblia in clinical and environmental samples in some regions of Baghdad city. Int. J. Curr. Microbiol. App. Sci., 5(4):459-468.

31. Kiran, T.; Shashwati, N.; Vishal, B. and Ashok-kumar, D. (2014). Intestinal Parasitic infections and Demographic status of school children in Bhopal region of Central India. IOSR J. Pharmacy and Biological. Sci., 9(5): 83-87.

32. Al-Taii, M.H. (1997). Study in epidemiological cryptospordum in Diyala province. MSc Thesis. Vet. Med. College. Baghdad Uni. Iraq.

33. AL-Gelany, B.A. (2003). An epidemiological and diagnostic study of cryptosporidium in the man and animal in Althahab Alabiydh Village. PhD Thesis. Vet. Med. College Baghdad. Uni. 
34. Minnat, T.R. (2014). Detection of gastrointestinal parasite infection of sheep and goats in Diyala Province/ Iraq. AlQadisiya. J. Vet. Med. Sci., 13(2):118-123.
35. Al-Kaabi, S.R. (2005). Epidemiological study of parasite causes diarrhea in the province of Diwaniyah. MSc Thesis. College of Vet. Med. Qadisiyah Uni.

$$
\begin{aligned}
& \text { التّوث الطقيلي لمياه الشُرب وانتشّار ها بين العاملين والأغنام }
\end{aligned}
$$

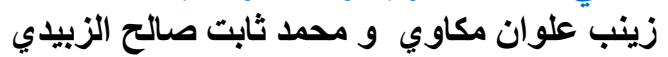

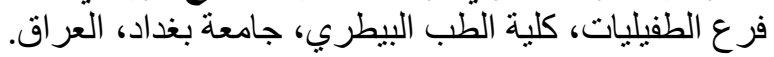

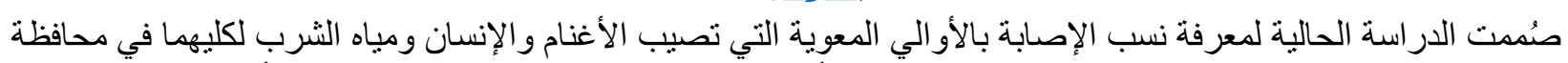

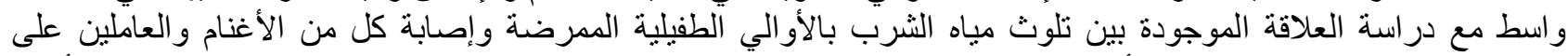

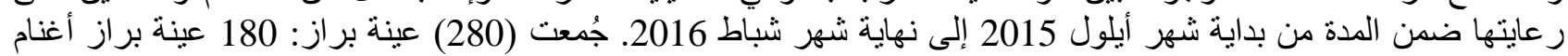

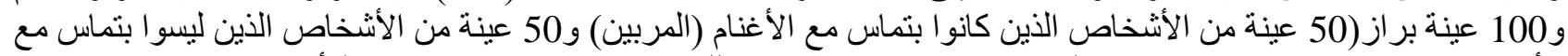

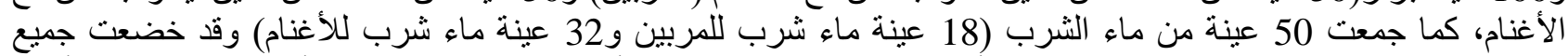

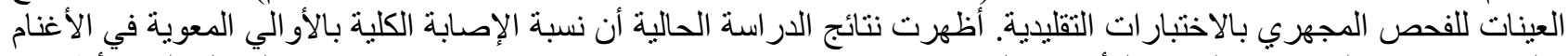

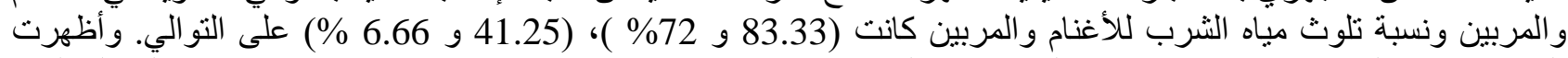

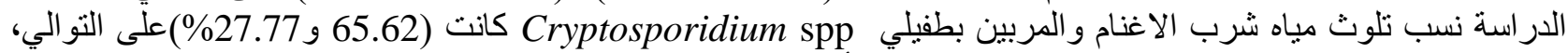

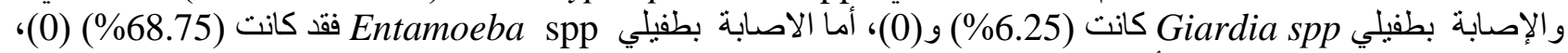

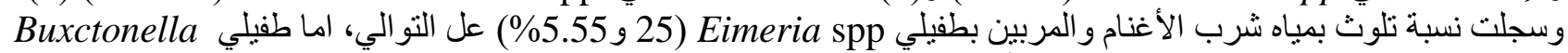

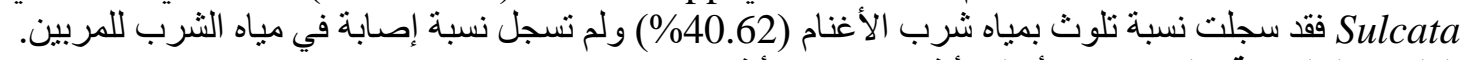
الكلمات المفتاحية: تلوث، ماءء، أوالي، أغنام، مربي الأغنام. 